\title{
Eco-Friendy Detoxification of Jatropha curcas L. Biodiesel from Heavy Metals Using Date Stone Adsorbent
}

\author{
MONA ALNAEEM ALHASSAN ${ }^{1}$, CHRISTINA YACOUB ISHAK ${ }^{1}$ \\ and M. EZELDIN OSMAN ${ }^{2 *}$ \\ ${ }^{1}$ Department of Chemistry, Faculty of Science, University of Khartoum, Khartoum, Sudan. \\ 2Peoples' Friendship University of Russia, Moscow 117198, Russia. \\ *Corresponding author E-mail: Wadalmsna3.com@gmail.com \\ http://dx.doi.org/10.13005/ojc/360302 \\ (Received: April 22, 2020; Accepted: May 25, 2020)

\begin{abstract}
Tranesteification of Jatropha curcus L. fixed oil gave biodiesel which is having of some heavy metals, such as, Nickel, Copper, Vanadium, Arsenic and Lead with high concentration that may be released during the combustion. Thus producing significant toxic impact on the engine and environment. Pulverized date stone adsorbent efficiently detoxify the crude biodiesel. The adsorption efficiency of metals has been determined by comparing the concentration of metals in the crude biodiesel before and after the passing through an adsorbent column. The effect of variation of adsorbent dose on adsorption efficiency and percentage of adsorption has been studied. The concentration of heavy metals in the biodiesel before treatment has been found to be 5.152, 1.283, 0.291, 1.137, 2.626, and 2.428 ppm for $\mathrm{Fe}, \mathrm{Ni}, \mathrm{Cu}, \mathrm{V}, \mathrm{As}$ and $\mathrm{Pb}$ respectively. Concentrations have revealed decrease after the treatment to $0.962,0.222,0.0327,0.150,0.314$, and $0.021 \mathrm{ppm}$ respectively. Pulverized date stone has shown marked efficiency in removing toxic heavy metals from Jatropha biodiesel. Adjustment of DS weight and length of column resulted in higher percent of metal adsorption. This technique is a contribution in the betterment of fuel via an eco-friendly method.
\end{abstract}

Keywords: Biodiesel, Date Stones, Heavy Metals, Adsorption.

\section{INTRODUCTION}

Biofuels are considered in part, a solution to such issues as sustainable development, energy security and a reduction of greenhouse gas emissions. Biodiesel an environmental friendly diesel fuel similar to petro-diesel in combustion properties $^{1}$, has received considerable attention in the recent past worldwide ${ }^{2}$. Potentially toxic trace elements such as Lead, Copper, vanadium,
Nickel and Arsenic with high level in biodiesel caused toxicity of environment ${ }^{3}$. Contamination of environmental compartments with organic and inorganic compounds such as metals and pesticides has motivated the development of purification and extraction methods ${ }^{4}$. Among several technologies, the extraction of metal ions using solid materials such as modified silica, alumina, activated carbon, and resins has been extensively investigated ${ }^{5-9}$. Recently bioadsorbents which produced from agro-

This is an Open Access article licensed under a Creative Commons license: Attribution 4.0 International (CC- BY). Published by Oriental Scientific Publishing Company @ 2018

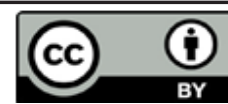


wastes may act as a significant material for heavy metals adsorption ${ }^{10-14}$. In this research work cheap, available, low cost, simplicity and more eco-friendly method has been applied to remove heavy metals from biodiesel by using pulverized date stone as adsorbent. The main objective of this research is determination of adsorption efficiency of pulverized date stone as adsorbent and to enhance the biodiesel synthesis from Jatropha curcas L. oil.

\section{MATERIALS AND METHODS}

\section{Materials}

Methanol, Hydrochloric acid, sodium hydroxide, sodium thiosulphate, glass wool, acetone and pulverized, Date stones. All chemicals used are of analytical reagent grade (AR)and used without any further purification, they were obta purchased from Sigma Chemical Co. (St.Louis, MO).

\section{EXPERIMENTAL}

\section{Preparation of raw oil}

The Jatropha curcas L. seeds have been collected from Blue Nile State (Aldmazien area). Fixed oil has been extracted by mechanical pressing according to the standard method described by $\mathrm{AOAC}^{15}$.

\section{Synthesis of biodiesel by Trans-esterification reaction using $\mathrm{NaOH}$ catalyst}

Fixed oil $100 \mathrm{~g}, 300 \mathrm{~g}$ methanol and sodium hydroxide $1 \mathrm{~g}$ have been mixed in $1 \mathrm{~L}$ round bottom flask in the ratio [1: $3: 0.01$ ] respectively. Then the mixture has been refluxed for $2 \mathrm{~h}$ at $\left(65^{\circ} \mathrm{C}\right)$. After completion of the reaction, the mixture has been transferred into $1 \mathrm{~L}$ separating funnel, two layers were obtained, the upper was the methyl esters (ME) and the lower was the glycerol. Glycerol layer has been discarded, and the methyl ester layer was washed with hot distilled water to remove polar substance finally, the methyl ester layer was dried with anhydrous $\mathrm{Na}_{2} \mathrm{SO}_{4}$ and kept for purification and assessment ${ }^{16,17}$.

\section{Preparation of adsorbent}

The date stones have been collected from the food manufacturing industries in a local market of Khartoum. Sample has been washed exhaustively with distilled and deionized water to remove edible part and dirt particles from the surface, and then oven dried $\left(45^{\circ} \mathrm{C}\right)$ for 24 hours. Then date stone was ground into fine powder and kept in airtight bottle for experimental uses.

\section{Characteristic of date stone}

Date stone powder has been analyzed on (Shimadzu instrument FTIR 8400S). The Fourier transform infrared (FTIR) spectroscopy was used to determine main functional groups of the adsorbent within the range of $400-4000 \mathrm{~cm}^{-1}$ wave number.

\section{Purification of biodiesel using DS adsorbent}

Chromatography column of $(10 \mathrm{~cm}$ height $/ 1.2 \mathrm{~cm}$ diameter) has been packed with glass wool at the bottom, and then was packed with a bed $(7.03 \mathrm{~g})$ of pulverized date stone. Then $(4 \mathrm{~mL})$ of acetone were added to column drop wise and allowed to pass through the adsorbent bed. Next, $20 \mathrm{~mL}$ of biodiesel were passed to the column with a flow rate of (12 drops/min) the above steps were repeated with different weight of adsorbent and length of column to determine the effects of it on adsorption efficiency and percentage of adsorption. The experiments have been carried out at $\left(27^{\circ} \mathrm{C}\right)$.

After terminations of the adsorption experiment, the remainingconcentrations of the metals in the biodiesel sample were determined by (ICP-AE). The percentage of adsorption (\%) was calculated using thefollowing equation (1):

$\%$ Adsorption $=\frac{(\mathrm{Ci}-\mathrm{Cf})}{\mathrm{Ci}} \times 100$

Where, $\mathrm{C}_{\mathrm{i}}$ is initial concentration $(\mathrm{mg} / \mathrm{L})$ of the metal ions in the sample solution (before passing through adsorbent column), $\mathrm{C}_{\mathrm{f}}$ is final concentrations $(\mathrm{mg} / \mathrm{L})$ of the metal ions in the sample solution (after passing through adsorbent column).

The efficiency of adsorption ( $\mathrm{mg} / \mathrm{g}$ ) was calculated using the following equation (2):

$$
\mathrm{q}(\mathrm{mg} / \mathrm{g})=[(\mathrm{Ci}-\mathrm{Cf}) \cdot V] / \mathrm{w}
$$

Where $\mathrm{q}$ is the efficiency of adsorption $(\mathrm{mg} / \mathrm{g}), \mathrm{C}_{i}$ is initial concentration $(\mathrm{mg} / \mathrm{L})$ of the metal ions in the sample solution (before passing through adsorbent column), $C_{f}$ is final concentrations ( $\mathrm{mg} / \mathrm{L}$ ) of the metal ions in the sample solution (after passing through adsorbent column), $\mathrm{V}$ is the volume of the sample solution ( $L$ ) and $w$ is the dry weight of the adsorbent $(\mathrm{g})^{18}$. 
Characterization of elements concentration in biodiesel before and after passing through DS adsorbent column using Inductively Coupled Plasma Atomic Emission Spectrometry (ICP-AE) technique. Instrumentation

The analytical determination of metals carried out by ICP-AE (Inductively Coupled Plasma -Atomic Emissions): ELAN 9000 (Perkin Elmer Instrument, Concord, Ontario, Canada).

\section{Calibration}

The ICP was carried out by external calibration with the blank solution and three working standard solutions (5, 10 and $20 \mu \mathrm{g} / \mathrm{L})$ for all elements.

\section{Sample preparation}

Biodiesel $(10 \mathrm{~g})$ has been transferred into a clean gosh crucible, then has been burned using muffle furnace at $550^{\circ} \mathrm{C}$ for 2 hours. The ash was dissolved in $10 \mathrm{~mL}$ concentrated hydrochloric acid, and then the extract was filtrated and transferred into $100 \mathrm{~mL}$ volumetric flask completed to the mark by deionized water and injected into instrument ${ }^{19}$.

Determination of ash content of synthesized biodiesel before and after treatment

Biodiesel sample (10 g) has been placed in a clean goshcrucible and heated for $1 \mathrm{~h}$ at $105^{\circ} \mathrm{C}$. Then carbonaceous residue has been ignited in muffle furnace at $550^{\circ} \mathrm{C}$ for $3 \mathrm{~h}$ until constant weight obtained. Then the crucible has been cooled and weighed finally the ash content was calculated.

\section{RESULTS AND DISCUSSION}

\section{Data obtained from FTIR}

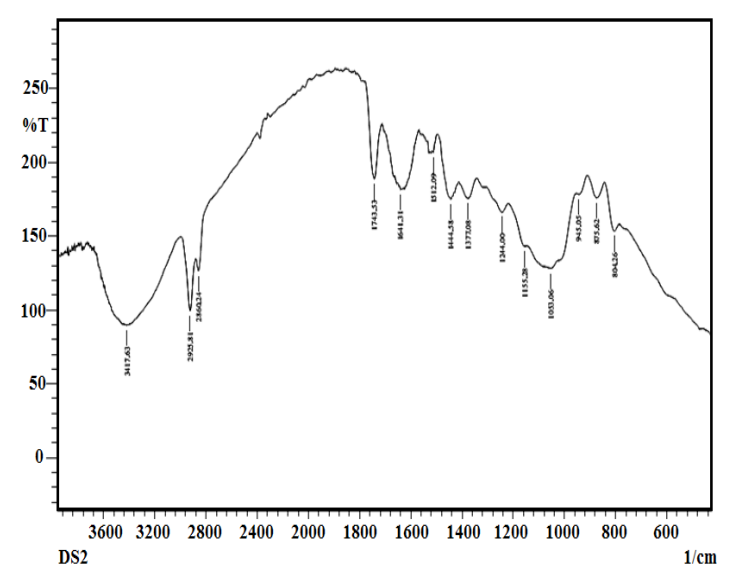

Fig.1. FTIR spectrum of pulverized DS
Figure (1) shows the FTIR spectrum of the pulverized DS. It depictssemi-broad band at the $3411.84 \mathrm{~cm}^{-1}$ assigned for $\mathrm{O}-\mathrm{H}$ stretching mode from hydroxyl group may be involved in hydrogen bonding. Double peaks at $2866.02-2927.74 \mathrm{~cm}^{-1}$ due to the $\mathrm{C}-\mathrm{H}$ stretching vibrations. Finally, the medium absorbance stretching peaks at $1741.60 \mathrm{~cm}^{-1}$ and $1643.24 \mathrm{~cm}^{-1}$ can be ascribed to $\mathrm{C}=\mathrm{O}$ groups that are highly conjugated stretching in carboxylic groups and carboxylic moieties.

Results obtained from the ICP-AE analysis Elements composition of biodiesel before treatment by DS adsorbent

Table 1.The elemental composition of Jatropha curcas biodiesel before treatment

\begin{tabular}{cc}
\hline Element & $\begin{array}{c}\text { Concentration }(\mathrm{mg} / \mathrm{L}) \text { in biodiesel } \\
\text { before passing through column }\end{array}$ \\
\hline $\mathrm{Na}$ & 5.157 \\
$\mathrm{Mg}$ & 10.156 \\
$\mathrm{Ca}$ & 28.782 \\
$\mathrm{Al}$ & 1.436 \\
$\mathrm{Fe}$ & 5.152 \\
$\mathrm{Ni}$ & 1.283 \\
$\mathrm{Cu}$ & 0.291 \\
$\mathrm{~V}$ & 1.137 \\
$\mathrm{As}$ & 2.626 \\
$\mathrm{~Pb}$ & 2.428 \\
\hline
\end{tabular}

Table (1) has shown that the highest metal concentrations have been those for $\mathrm{Ca}, \mathrm{Mg}, \mathrm{Na}$ and Fe. Besides AS, Pb, Niand V metals have shown high concentration. That high concentration detected can damage fuel injection system and cause combustion chamber deposits and also might cause pollution of environment.

\section{Elements Composition of biodiesel after treatment by DS adsorbent}

The obtained results have depicted that heavy metal concentration have appreciably been decreased after treatment using pulverized DS adsorbent.

Data illustrated the effect of column length on the adsorption percentage and adsorption efficiency. It has been observed that both adsorption percentage and efficiency of adsorption has been increased when the amount of adsorbent has been doubled. In general the increase of adsorbent weight caused the increase of surface area and active sites for attraction of adsorbate. 
Table 2: Elemental composition of Jatropha curcas biodiesel after passing through column ( $10 \mathrm{~cm}$ length $/ 1.2 \mathrm{~cm}$ diameter $/ 7.03 \mathrm{~g}$ of adsorbent)

\begin{tabular}{ccccc}
\hline Element & $\begin{array}{c}\text { Concentration (mg/L) in biodiesel } \\
\text { before pass through column }\end{array}$ & $\begin{array}{c}\text { Concentration (mg/L) in biodiesel } \\
\text { after pass through column }\end{array}$ & $\begin{array}{c}\text { Percentage of } \\
\text { adsorption \% }\end{array}$ & $\begin{array}{c}\text { Efficiency of } \\
\text { adsorption (mg/g) }\end{array}$ \\
\hline $\mathrm{Na}$ & 5.157 & 4.309 & 16.44 & 0.00241 \\
$\mathrm{Mg}$ & 10.156 & 7.911 & 22.10 & 0.00638 \\
$\mathrm{Ca}$ & 28.782 & 24.469 & 14.98 & 0.0122 \\
$\mathrm{Al}$ & 1.436 & 1.248 & 13.10 & 0.000535 \\
$\mathrm{Fe}$ & 5.152 & 2.348 & 54.43 & 0.00797 \\
$\mathrm{Ni}$ & 1.283 & 0.857 & 33.20 & 0.00121 \\
$\mathrm{Cu}$ & 0.291 & 0.226 & 22.33 & 0.000185 \\
$\mathrm{~V}$ & 1.137 & 0.806 & 29.11 & 0.000941 \\
$\mathrm{As}$ & 2.626 & 1.751 & 33.33 & 0.00248 \\
$\mathrm{~Pb}$ & 2.428 & 1.625 & 33.0 & 0.00228 \\
\hline
\end{tabular}

Table 3: Elemental composition of Jatropha curcas biodiesel after passing through column (20 cm length/1.2 cm diameter/14.60 g of adsorbent)

\begin{tabular}{ccccc}
\hline Element & $\begin{array}{c}\text { Concentration }(\mathrm{mg} / \mathrm{L}) \text { in biodiesel } \\
\text { before pass through column }\end{array}$ & $\begin{array}{c}\text { Concentration }(\mathrm{mg} / \mathrm{L} \text { ) in biodiesel } \\
\text { after pass through column }\end{array}$ & $\begin{array}{c}\text { Percentage of } \\
\text { adsorption \% }\end{array}$ & $\begin{array}{c}\text { Efficiency of } \\
\text { adsorption (mg/g) }\end{array}$ \\
$\mathrm{Na}$ & 5.157 & 0.717 & 83.36 & 0.00608 \\
$\mathrm{Mg}$ & 10.156 & 0.401 & 96.05 & 0.0133 \\
$\mathrm{Ca}$ & 28.782 & 8.540 & 70.32 & 0.0277 \\
$\mathrm{Al}$ & 1.436 & 0.562 & 60.86 & 0.00119 \\
$\mathrm{Fe}$ & 5.152 & 1.203 & 76.64 & 0.00540 \\
$\mathrm{Ni}$ & 1.283 & 0.311 & 75.75 & 0.00133 \\
$\mathrm{Cu}$ & 0.291 & 0.0331 & 88.62 & 0.000353 \\
$\mathrm{~V}$ & 1.137 & 0.164 & 86.10 & 0.00133 \\
$\mathrm{As}$ & 2.626 & 0.413 & 84.27 & 0.00303 \\
$\mathrm{~Pb}$ & 2.428 & 0.021 & 99.13 & 0.00329 \\
\hline
\end{tabular}

Table 4: Elemental composition of Jatropha curcas biodiesel after passing through column (30 cm length/1.2 cm diameter/ $21.02 \mathrm{~g}$ of adsorbent)

\begin{tabular}{ccccc}
\hline Element & $\begin{array}{c}\text { Concentration }(\mathrm{mg} / \mathrm{L} \text { ) in biodiesel } \\
\text { before pass through column }\end{array}$ & $\begin{array}{c}\text { Concentration (mg/L) in biodiesel } \\
\text { after pass through column }\end{array}$ & $\begin{array}{c}\text { Percentage of } \\
\text { adsorption \% }\end{array}$ & $\begin{array}{c}\text { Efficiency of } \\
\text { adsorption (mg/g) }\end{array}$ \\
\hline $\mathrm{Na}$ & 5.157 & 0.318 & 92.62 & 0.00460 \\
$\mathrm{Mg}$ & 10.156 & 0.336 & 96.69 & 0.00934 \\
$\mathrm{Ca}$ & 28.782 & 6.263 & 78.23 & 0.0214 \\
$\mathrm{Al}$ & 1.436 & 0.537 & 62.60 & 0.000855 \\
$\mathrm{Fe}$ & 5.152 & 0.962 & 81.32 & 0.00398 \\
$\mathrm{Ni}$ & 1.283 & 0.222 & 82.69 & 0.001009 \\
$\mathrm{Cu}$ & 0.291 & 0.0327 & 88.76 & 0.000245 \\
$\mathrm{~V}$ & 1.137 & 0.150 & 86.80 & 0.000939 \\
$\mathrm{As}$ & 2.626 & 0.314 & 88.04 & 0.002199 \\
$\mathrm{~Pb}$ & 2.428 & 0.021 & 99.13 & 0.00229 \\
\hline
\end{tabular}

Data from Table (3) revealed that the increase of DS weight and the length of column gave a significant improvement of both percentage and efficiency adsorption. Besides the toxic heavy metals concentrations have gone very low and lead $(\mathrm{Pb})$ has almost been eradicated.

The comparison of data obtained from Table (3) and Table (4) has shown a slight increase in the percentage of adsorption of metal ions due to the increase of weight of DS, but the efficiency of adsorption has decrease, hence it can be concluded that the optimal weight and length of column were as depicted in Table (3).

Figure 3 showed the effect of adsorbent doses on the adsorption percentage. The study was carried out to optimize the required amount of the 
adsorbent for maximum uptake efficiency at room temperature of $27^{\circ} \mathrm{C}$, and flow rate of 12 drops/minute. Percentage of $\mathrm{Fe}, \mathrm{Ni}, \mathrm{Cu}, \mathrm{V}, \mathrm{As}$ and $\mathrm{Pb}$ ions uptake by DS adsorbent increased with higher percentage from $54.43,33.20,22.33,29.11,33.33$ and $33 \%$ to 81.32 , $82.69,88.76,86.80,88.04$ and $99.13 \%$ respectively when the adsorbents doses was increased from 7.03 to $21.02 \mathrm{~g}$. These results can be attributed to increase of adsorbent sites due to increase of adsorbent dose which enhancing metals removal.
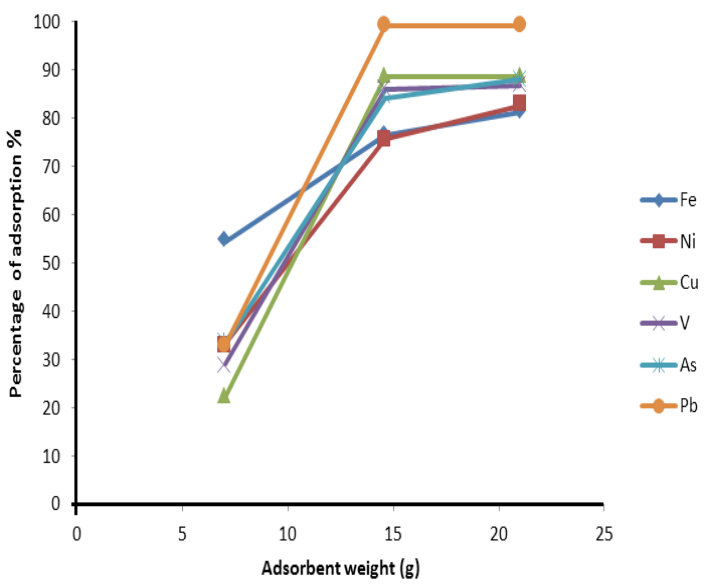

Fig. 2. Effect of adsorbent dosage on the adsorption of Fe, $\mathrm{Ni}, \mathrm{Cu}, \mathrm{V}, \mathrm{As}$ and $\mathrm{Pb}$ using pulverized $\mathrm{DS}$ adsorbent (T: $27^{\circ} \mathrm{C}$; flow rate 12 drops/minute)

Comparison between obtained results before and after passage through DS adsorbent illustrated the amount of adsorbate taken up by the adsorbent (Figure 3).

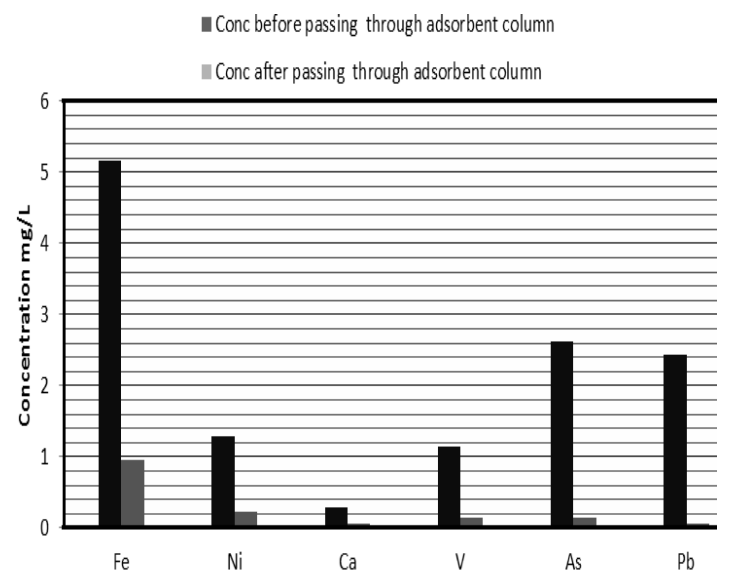

Fig. 3. Comparison between the concentration of $\mathrm{Fe}, \mathrm{Ni}$, $\mathrm{Cu}, \mathrm{V}, \mathrm{As}$ and $\mathrm{Pb}$ in the sample before and after passage through DS adsorbent

Adsorption is a surface phenomenon; it is a consequence of surface energy. Atoms on the surface of adsorbent are not wholly surrounded by other adsorbent atoms therefore can attract adsorbates. As depicted by FTER spectrum carboxylate anions and hydrogen bonding functionalities are site for adsorbate attraction (Fig. 1). Results also have a clarified that, the increase of surface area by the increase of mass of the rigid particles (DS) packed in a column during chromatography sorption process; the adsorbates-metal ions- are selectively transferred from the liquid phase to the surface of the pulverized date stone. The exact nature of the bonding depends on details of the species involved (Fig. 2 and 3).

$\begin{gathered}\text { Ash content of biodiesel before and after } \\ \text { treatment with DS adsorbent }\end{gathered}$
Table 5: Ash content of Jatropha curcas biodiesel
before and after treatment

Data reveals the depletion of heavy metals as consequence of looking of the ash content in the biodiesel that approached the permissible limits assigned by ASTM specification ${ }^{20,21}$.

The obtained results revealed that: the bio-adsorbent pulverized DS which has been fully characterized proved to be an efficient adsorbent. It has almost fully eradicated the toxic heavy metals The technique has led to produce biodiesel as genuine natural biofuel free off $\mathrm{Pb}$ element with an ash content of $0.011(\% \mathrm{w} / \mathrm{w})$.

\section{ACKNOWLEDGEMENT}

We would like to express our special thanks to Central Petroleum Laboratories and Alawia Imam Institute for Pharmaceutical Research and Development, University of Medical Science and Technology for their assistance and help in the chemical analysis. 


\section{REFERENCES}

1. Dincer I. Renewable energy and sustainable development: a crucial review. Renewable and sustainable energy reviews., 2000, 4(2),157-75.

2. Parawira W. Biodiesel production from Jatropha curcas: A review. Scientific Research and Essays., 2010, 5(14),1796-808.

3. Falahi-Ardakani A. Contamination of environment with heavy metals emitted from automotives. Ecotoxicology and environmental safety., 1984, 8(2), 152-61.

4. Minello MC, Paco AL, Martines MA, Caetano L, Santos AD, Padilha PM, Castro GR. Sediment grain size distribution and heavy metals determination in a dam on the Paraná River at Ilha Solteira, Brazil. Journal of Environmental Science and Health, Part A., 2009, 44(9), 861-5.

5. Huang X, Chang X, He Q, Cui Y, Zhai Y, Jiang $N$. Tris (2-aminoethyl) amine functionalized silica gel for solid-phase extraction and preconcentration of $\mathrm{Cr}$ (III), $\mathrm{Cd}$ (II) and $\mathrm{Pb}$ (II) from waters. Journal of hazardous materials., 2008, 157(1), 154-60.

6. Sheibani M, Marahel F, Ghaedi M, Montazerozohori M, Soylak M. Preconcentration of some trace metal ions on coated alumina modified by 1-((6-(-(2-hydroxynaphthalen1-yl) methyleneamino) hexylimino) methyl) naphthalen-2-ol. Toxicological and Environmental Chemistry., 2011, 93(5), 860-72.

7. Ghaedi M, Ahmadi F, Tavakoli Z, Montazerozohori M, Khanmohammadi A, Soylak M. Three modified activated carbons by different ligands for the solid phase extraction of copper and lead. Journal of hazardous materials., 2008, 152(3), 1248-55.

8. Verbych S, Hilal N, Sorokin G, Leaper M. Ion exchange extraction of heavy metal ions from wastewater. Separation science and technology., 2005, 39(9), 2031-40.

9. Wongkaew M, Imyim A, Eamchan P. Extraction of heavy metal ions from leachate of cementbased stabilized waste using purpurin functionalized resin. Journal of hazardous materials., 2008, 154(1-3), 739-47.

10. Castro, R. S., Caetano, L., Ferreira, G., Padilha, P. M., Saeki, M. J., Zara, L. F., \& Castro, G. R. Banana peel applied to the solid phase extraction of copper and lead from river water: preconcentration of metal ions with a fruit waste. Industrial \& Engineering Chemistry
Research., 2011, 50(6), 3446-3451.

11. Amarasinghe, B.M; Williams, R. A. Tea waste as a low cost adsorbent for the removal of $\mathrm{Cu}$ and $\mathrm{Pb}$ from wastewater. Chemical Engineering Journal., 2007, 132(1-3), 299-309.

12. Šciban, M.; Klašnja, M.; Škrbic B. Modified softwood sawdust as adsorbent of heavy metal ions from water. Journal of hazardous materials., 2006, 136(2), 266-71.

13. Hossain, M. A,; Ngo, H. H; Guo, W. S; Nguyen, T. V. Removal of copper from water by adsorption onto banana peel as bioadsorbent. International Journal of Geomate., 2012, 2(2), 227-34.

14. Rahman, M. S.; Islam, M. R. Effects of $\mathrm{pH}$ on isotherms modeling for $\mathrm{Cu}$ (II) ions adsorption using maple wood sawdust. Chemical Engineering Journal., 2009, 149(1-3), 273-80.

15. Williams, S. ur. Official methods of analysis. Arlington, VA: Association of Official Analytical Chemists/AOAC.,1984.

16. Jain, S.; Sharma, M. P. Kinetics of acid base catalyzed transesterification of Jatropha curcas oil. Bioresource technology., 2010, 101(20), 7701-6.

17. Osman, M. E. A. Methods for the Improvement of Physicochemical Parameters of Petrodiesel and Jatropha curcas L Biodiesel Using Eco-friendly Materials and Gamma Radiation (Doctoral dissertation. Sudan University of Science and Technology., 2018.

18. Abudaia, J. A.; Sulyman, M. O.; Elazaby, K.; Ben-Ali, S. M. Adsorption of $\mathrm{Pb}$ (II) and $\mathrm{Cu}$ (II) from aqueous solution onto activated carbon prepared from dates stones. International Journal of Environmental Science and Development., 2013, 4(2), 191.

19. Knothe, G.; Dunn, R. O. Dependence of oil stability index of fatty compounds on their structure and concentration and presence of metals. Journal of the American Oil Chemists' Society., 2003, 80(10), 1021-6.

20. Ishak, C.Y.; Hassan, E. A.; Ezeldin, M.; Alnaeem, M. Physico-Chemical Properties and Elements Composition of Fixed oil, Seed Extract, of Jatropha curcus L. [Blue Nile State (Aldamazien)]. Academic Journal of Chemistry., 2017, 2(8), 84-9.

21. Salvter, J.Rand. Annual book of ASTM standard. American Society for Testing and Materials. West Conshohocken., 2005. 